\title{
Vitamin E supplementation during the dry period in dairy cattle. Part I: Adverse effect on incidence of mastitis postpartum in a double-blind randomized field trial
}

\author{
R. J. Bouwstra, ${ }^{* 1}$ M. Nielen, ${ }^{\star}$ J. A. Stegeman, ${ }^{\star}$ P. Dobbelaar, ${ }^{\star}$ J. R. Newbold, $†$ E. H. J. M. Jansen,‡ \\ and T. van Werven* \\ *Faculty Veterinary Medicine, Department of Farm Animal Health, Utrecht University, $3584 \mathrm{CL}$, the Netherlands \\ †Provimi Research and Innovation Centre, 1932 Sint-Stevens-Woluwe, Brussels, Belgium \\ ¥National Institute for Public Health and the Environment, 3721 MA Bilthoven, the Netherlands
}

\begin{abstract}
A randomized, controlled field trial with dairy cows demonstrated an adverse effect of vitamin E supplementation during the dry period on mastitis incidence in early lactation. This study was conducted on farms with historically high rates of mastitis to investigate the benefit of vitamin E supplementation on udder health; however, the outcome showed an adverse effect. The aim of the study was to evaluate whether daily supplementation of 3,000 IU of vitamin E to dairy cows during the dry period could improve udder health in commercial herds with a high incidence of mastitis. On 5 dairy farms, dry cows were randomly divided into 2 experimental groups: a high and a low group. Both groups received a dry cow mineral mix providing 3,000 or 135 IU of vitamin E/cow per day, respectively, between dry-off and calving for a mean period of 8 wk. Providing 3,000 IU of vitamin E exceeds NRC standards, but this amount has been used in previous studies. The experiment, as well as the majority of the statistical analysis, were carried out blinded. Blood was sampled 3 times before calving and on calving day. Serum was analyzed for vitamin $\mathrm{E}$ and cholesterol. Vitamin $\mathrm{E}$ and the vitamin E:cholesterol ratio were analyzed as dependent variables in mixed models and Student's $t$-tests to study trends in time and differences between groups. Relative risk calculation and survival analysis were used to study the effect of supplementation on mastitis incidence in the first 3 mo of lactation. The results showed that vitamin $\mathrm{E}$ supplements increased both absolute vitamin $\mathrm{E}$ and the ratio of vitamin $\mathrm{E}$ to cholesterol in blood. In the high group, significantly more subclinical and clinical cases occurred, showing the same trend on all farms. In this study, an initial vitamin E level at
\end{abstract}

Received February 10, 2010.

Accepted September 12, 2010.

${ }^{1}$ Corresponding author: r.j.bouwstra@uu.nl dry off above $14.5 \mu \mathrm{mol} / \mathrm{L}$ was a risk factor for clinical mastitis, suggesting that the vitamin E status at the start of the dry period is important. It is recommended to work out exactly at what threshold vitamin $\mathrm{E}$ is harmful for udder health before new trials with high dosages of vitamin E are started. Additionally, further research is required to investigate the mechanism by which vitamin $\mathrm{E}$ affects udder health.

Key words: adverse effect, dairy dry cow, mastitis, vitamin $\mathrm{E}$

\section{INTRODUCTION}

Based on the hypothesized association of periparturient disorders with low antioxidant status of cows just around calving (Goff and Stabel, 1990; Weiss et al., 1990b), several large clinical trials have been conducted to investigate the hypothesized benefit of antioxidant supplements in disease prevention (Smith et al., 1984; Weiss et al., 1990a; Baldi et al., 2000). Special emphasis was placed on vitamin $\mathrm{E}$ as it is considered the most important chain-breaking, lipid-soluble antioxidant (Burton and Traber, 1990) and because it lowers oxidative stress and improves the health of dairy cows (Miller et al., 1993).

It is well accepted that vitamin E supplementation during the dry period has a positive effect on the udder health of dairy cows in early lactation as various studies reported a reduced incidence of (sub)clinical mastitis after supplementation (Smith et al., 1984; Weiss et al., 1990a). The initial vitamin E status of the animals in these older studies might have been different in comparison with more recent studies showing no effect of vitamin E supplementation on udder health (LeBlanc et al., 2004; Persson Waller et al., 2007). Over the last 10 yr, feeding strategies may have changed due to positive reports and new recommendations for supplementation (NRC, 2001). Vitamin E might only have a positive effect in studies where cows started with a marginal or deficient vitamin E status, which then improved dur- 
ing the trial because of the high level of vitamin $\mathrm{E}$ supplementation.

In contrast to human literature, only positive or neutral effects of vitamin E supplements have been reported in dairy cows. Recent evidence from large clinical trials and meta-analyses in humans has indicated vitamin E-mediated negative side effects (Miller et al., 2005; Brigelius-Flohé, 2007; Winterbone et al., 2007). Such adverse effects of high amounts of vitamin E might also exist in dairy cows. This paper will focus on results gathered in a randomized clinical trial, originally conducted to demonstrate the benefit of high amounts of vitamin E supplemented during the dry period on udder health in early lactation.

The aim of the study was to evaluate the effect on udder health of a daily supplement of 3,000 IU of vitamin $\mathrm{E}$ to dairy cows during the dry period compared with a daily supplement of $135 \mathrm{IU}$ in commercial herds in the Netherlands with a high incidence of mastitis. The vitamin $\mathrm{E}$ level in the dry cow mineral mix fed to the high group was higher than the NRC (2001) recommendations of $1.8 \mathrm{IU}$ of vitamin $\mathrm{E} / \mathrm{kg}$ of $\mathrm{BW}$ in the dry period. Although 3,000 IU of vitamin E/d is not recommended by the NRC (2001), it is not an unusual amount. Positive effects on udder health (Weiss et al., 1997; Baldi et al., 2000), function of bovine leucocytes (Politis et al., 2004), and the antioxidant status on liver level (Bouwstra et al., 2008) were reported with 2,000, 4,000 (last $14 \mathrm{~d}$ of the dry period), and 3,000 IU of vitamin E, respectively. Based on these results, we hypothesized that treatment with 3,000 IU of vitamin $\mathrm{E} / \mathrm{d}$ would improve udder health in early lactation.

\section{MATERIALS AND METHODS}

The experiment was conducted in the Netherlands. The Committee for Animal Experiments at Utrecht University approved the experimental protocol. The set up of the study was triple blind to reduce the possibility of bias due to field study workers. Triple blind means that farmers and the complete research group were blind to group assignment. Moreover, the data analyst was also blind to group until most analyses were finished.

\section{Animals}

The experiment was carried out from August 2007 until July 2008 with 296 Holstein Friesian dairy cows from 5 commercial dairy herds in the Netherlands. Herds were selected using the following criteria: the possibility of dividing the dry cows into 2 separate feeding groups, a minimum of 100 milking cows, a mean milk production of 8,000 to $10,000 \mathrm{~kg} / \mathrm{yr}$, a mean dry-period length of at least $6 \mathrm{wk}$, participation in the official milk-recording program, no use of a robotic milking system, and at least 30 clinical mastitis cases/100 cows per year or 15 new subclinical cow cases (SCC >250,000 cells $/ \mathrm{mL}$ )/ mo per 100 cows in the previous 12 mo. Three farms (A, B, C) mainly had clinical mastitis problems and 2 (D, E) mainly had subclinical mastitis problems. On each farm, 52 to 70 cows were selected and randomly divided over the 2 experimental groups. In 3 farms (B, $\mathrm{D}, \mathrm{E})$, heifers were included in the experiment as a separate randomization and heifers were housed in the same pens as the dry cows of the same experimental group. The trial was done at the same time of the year on all farms from August 2007 until July 2008, and cows were split into 2 groups on farms and fed as 2 groups at the same time on the 5 single farms. On all farms, dry cows and lactating cows selected for the experiment were housed in cubicle barns. The cows and heifers in the low group $(\mathrm{n}=148)$ received $100 \mathrm{~g} / \mathrm{d}$ of a mineral mix providing 135 IU of DL- $\alpha$-tocopherylacetate/d, and cows and heifers in the high group (n $=148$ ) received $100 \mathrm{~g} / \mathrm{d}$ of a mineral mix providing 3,000 IU of DL- $\alpha$-tocopheryl-acetate/d (Provimi BV, Rotterdam, the Netherlands). Other vitamins and minerals in the dry cow mineral mixes were equal and were according to Dutch standards for dry cow supplements. The exact formulation is described in Table 1. The mineral mix was top-dressed over the feed during the entire dry period. Within the 5 farms, stocking density did not differ between the 2 experimental groups. The main forage fed was wilted grass silage. Additional corn silage was fed, but exact amounts differed between farms. Cows did not have access to green pasture and no fresh grass was fed during the experiment. After calving, the cows in the 2 experimental groups were housed together with the rest of the lactating animals in cubicle barns, and from that moment on, cows were on the same diet of mainly wilted grass silage, corn silage, and concentrates.

\section{Definitions of the Outcomes}

To investigate udder health, 2 primary outcomes were defined, namely clinical and subclinical mastitis. A clinical quarter case was farmer-defined as any abnormalities visible on the cow, udder, and possibly in the milk. Abnormalities defined for the cow were a listless cow with or without an abnormal body temperature and a possible reduced appetite related to any abnormalities in the udder, milk, or both. Abnormalities defined for the udder were a red, swollen, and possibly painful udder. Abnormalities defined for the milk were watery milk and milk containing clots, with or without pus. When a farmer noticed a clinical quarter case, he 
Table 1. Formulation of the dry cow mineral mix

\begin{tabular}{lll}
\hline Product & Nutrient $/ \mathrm{kg}$ & $\begin{array}{l}\text { Nutrient } / 0.1 \mathrm{~kg} \\
\text { (amount fed per day) }\end{array}$ \\
\hline Elements & & \\
$\mathrm{Ca}$ & $10 \mathrm{~g}$ & $1 \mathrm{~g}$ \\
$\mathrm{P}$ & $40 \mathrm{~g}$ & $4 \mathrm{~g}$ \\
$\mathrm{Mg}$ & $175 \mathrm{~g}$ & $17.5 \mathrm{~g}$ \\
$\mathrm{Na}$ & $70 \mathrm{~g}$ & $7 \mathrm{~g}$ \\
$\mathrm{Zn}$ & $2,000 \mathrm{mg}$ & $200 \mathrm{mg}$ \\
$\mathrm{Fe}$ & $0 \mathrm{mg}$ & $0 \mathrm{mg}$ \\
$\mathrm{Cu}$ & $2,200 \mathrm{mg}$ & $220 \mathrm{mg}$ \\
$\mathrm{Co}$ & $30 \mathrm{mg}$ & $3 \mathrm{mg}$ \\
$\mathrm{Mn}$ & $2,400 \mathrm{mg}$ & $240 \mathrm{mg}$ \\
$\mathrm{I}$ & $65 \mathrm{mg}$ & $6.5 \mathrm{mg}$ \\
$\mathrm{Se}$ & $27 \mathrm{mg}$ & $2.7 \mathrm{mg}$ \\
Vitamins & & \\
$\mathrm{A}$ & $500,000 \mathrm{IU}$ & $50,000 \mathrm{IU}$ \\
$\mathrm{D}_{3}$ & $125,000 \mathrm{IU}$ & $12,500 \mathrm{IU}$ \\
$\mathrm{E}$ & 30,000 or $1,350 \mathrm{IU}$ & $3,000 \mathrm{or} 135 \mathrm{IU}$ \\
\hline
\end{tabular}

or she contacted the emergency service of the research team directly. Within $24 \mathrm{~h}$, the farm with the diseased cow was visited by a veterinarian and the diagnosis of clinical mastitis was confirmed or not. Farmers and all employees of the farms were trained by one veterinarian to recognize new clinical cases that were recorded on the quarter level. A subclinical case was defined as a first SCC elevation above 100,000 cells/mL, at between 5 to 100 DIM, not related to a clinical infection. Retrospectively, high-SCC cows had mean SCC of $>100,000$ cells/mL for the last 3 milk records before dry off and the first milk record after calving; these cows were not used in the statistical analysis $(\mathrm{n}=42)$ for subclinical mastitis. In all analyses, only first SCC elevations after calving were used. The SCC data per cow were collected every $4 \mathrm{wk}$ from the official milk-recording program up to 3 mo after calving.

\section{Blood Sampling}

All cows were sampled 4 times: at dry off, 4 and 2 wk before expected calving day, and within $24 \mathrm{~h}$ after calving. Except for the sample on day of calving, all samples were collected between 0800 and $1200 \mathrm{~h}$. Samples were kept at 6 to $10^{\circ} \mathrm{C}$ before they arrived at the laboratory. Mean time from sampling until arrival in the laboratory was $3 \mathrm{~h}$. Blood was collected from the jugular vein with BD Vacutainer systems (Becton Dickinson, Plymouth, UK). Blood samples were collected in a SST II Advance tube (Becton Dickinson) and centrifuged for $15 \mathrm{~min}$ at $3,500 \times g$, at $4^{\circ} \mathrm{C}$. Sera were frozen at $-80^{\circ} \mathrm{C}$ until analysis. Serum was analyzed for vitamin $\mathrm{E}$ and cholesterol.

\section{Laboratory Analysis}

Vitamin E ( $\alpha$-tocopherol) was measured by an isocratic HPLC method with a kit from Chromsystems
(Munich, Germany). The kit contained reagents, internal standard, calibration standards, an HPLC column, and mobile phase. The HPLC equipment comprised components from Varian (Middelburg, the Netherlands). Detection occurred with fluorescence detection.

Cholesterol concentration was determined on a clinical autoanalyzer (Hitachi 912, Roche Diagnostics, Almere, the Netherlands) using kits from Roche Diagnostics. All analyses were performed at the National Institute for Public Health and the Environment (Bilthoven, the Netherlands). Because the absolute concentration of vitamin $\mathrm{E}$ is affected by stage of lactation and dietary fat, the vitamin E:cholesterol ratio also was used to investigate the vitamin E status (Herdt and Smith, 1996).

\section{Statistical Analysis}

Sample Size. A priori power analysis was conducted to determine an appropriate sample size based on the following assumptions and criteria: minimum farm level mastitis rate of $25 \%$, a reduction of mastitis incidence of $50 \%$ in the high group, confidence interval of $95 \%$, and a power of $80 \%$. The needed sample size per experimental group was 152 for 2 -sided tests. In total, 344 animals were enrolled to achieve this number of animals. Finally, 296 cows were included in the analysis (Figure 1). Primiparous cows were included in all analyses.

Group and Group $\times$ Time Interaction. To find trends in time and differences between groups, vitamin $\mathrm{E}$ and the vitamin E:cholesterol ratio were studied with Student's $t$-test for each time period and in mixed models. For all analyses, vitamin $\mathrm{E}$ and the vitamin E:cholesterol ratio were log-transformed because the residuals looked more normally distributed this way. A model with treatment group, time, parity, and treatment group $\times$ time interaction as fixed effects, and cow, time, farm, and time and cow within farm as random effects was fitted using REML for the random effects and maximum likelihood (ML) for the fixed effects. The difference between treatment groups during the dry period was tested with the treatment group $\times$ time interaction effect. Vitamin $\mathrm{E}$ and the vitamin E:cholesterol ratio levels at 4 and 2 wk antepartum and at calving were tested relative to the first-measurement, dry-off levels. To investigate whether vitamin E levels differed between healthy cows and cows developing clinical mastitis, vitamin E was studied with Student's $t$-test for each period. In the aforementioned Student's $t$-test analyses, significance was set at $P<0.0125$, according to Bonferroni's correction for multiple tests. To investigate whether initial vitamin E status differed between multiparous and primiparous cows, mean vitamin $\mathrm{E}$ blood concentrations at dry off were compared using 
Student's t-tests. All models were built in R (v. 2.11.0, $\mathrm{R}$ Foundation for Statistical Computing, Vienna, Austria), and Student's t-tests were carried out in SPSS 12.0.1 for Windows. Significance was set at $P<0.05$.

Relative Risk. The relative risk of cumulative subclinical and clinical mastitis incidence in both groups was calculated with a stratified cohort analysis. First clinical quarter cases from 0 to 100 DIM and first subclinical cow cases from 5 to 100 DIM were used in these analyses. In addition, the relative risk of "high vitamin E at dry off" on clinical mastitis to 100 DIM was calculated for the high and low group and overall. A vitamin E concentration of $14.5 \mu \mathrm{mol} / \mathrm{L}$ was defined as "high at dry off" based on a report by Baldi (2005). Relative risk analyses were carried out in Win Episcope 2.0 (Thrusfield et al., 2001).

Survival Analysis. Survival analysis with group as fixed effect and farm as random (frailty) effect was used to evaluate whether the rate of clinical and subclinical mastitis differed between the high and low groups up

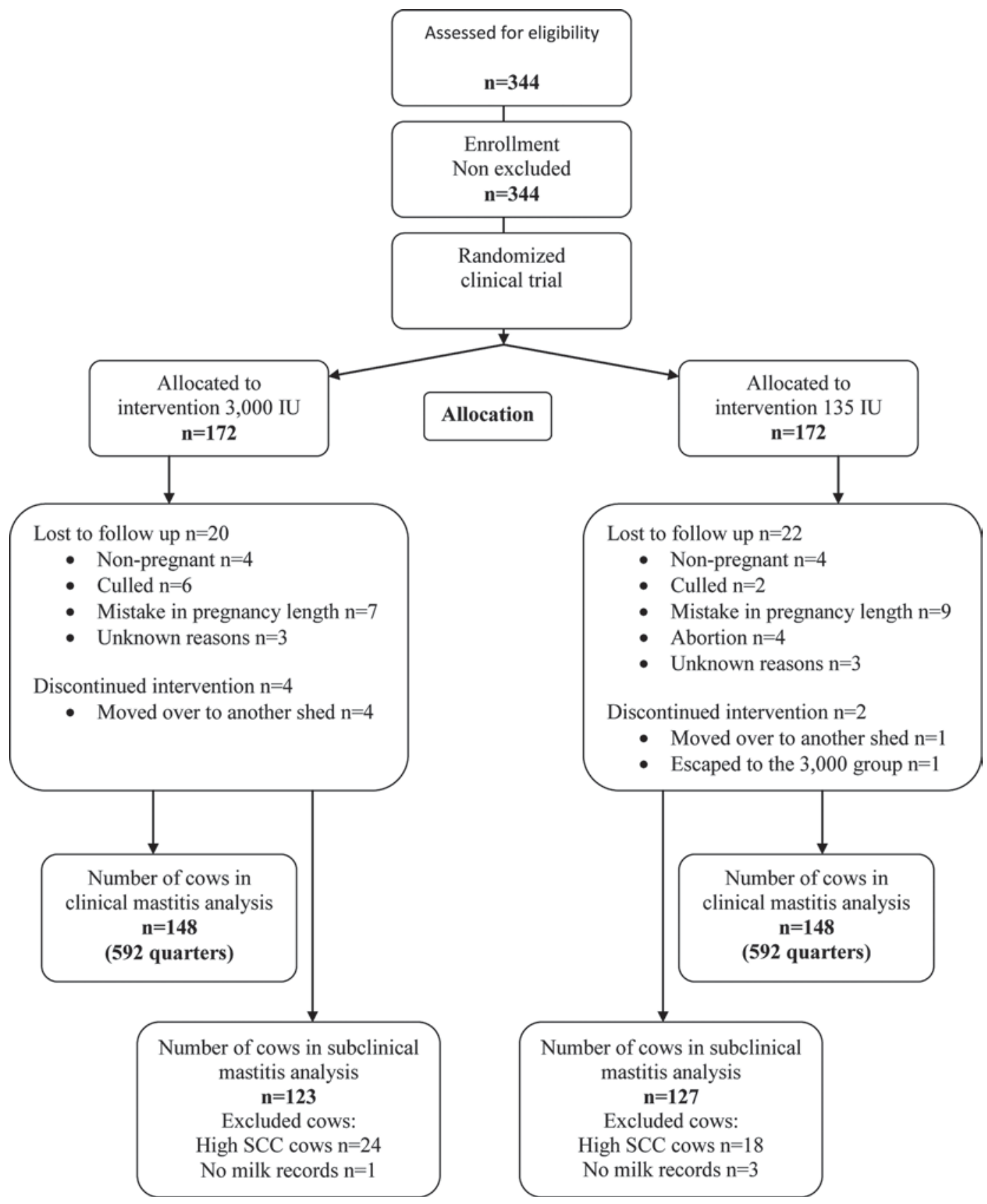

Figure 1. Flowchart of the randomized clinical trial. 
Table 2. Herd size, number of enrolled cows, milk quota, kilograms of milk per cow per day, fat and protein content (\%), clinical mastitis cases per 100 cows per year, mean percentage of monthly new subclinical cow cases (SCC >250,000 cells $/ \mathrm{mL}$ ) per 100 cows in the previous 12 mo, and annual bulk milk SCC at the time of selection

\begin{tabular}{lccccc}
\hline & \multicolumn{5}{c}{ Farm } \\
\cline { 2 - 6 } Item & $\mathrm{A}$ & $\mathrm{B}$ & $\mathrm{C}$ & $\mathrm{D}$ & $\mathrm{E}$ \\
\hline Farm & 165 & 125 & 462 & 139 & 117 \\
$\quad$ Herd size, $\mathrm{n}$ & 57 & 58 & 72 & 53 & 56 \\
$\quad$ Enrolled, $\mathrm{n}$ & 1.1 & 1.1 & 4.0 & 1.2 & 1.1 \\
$\quad$ Milk quota, $\times 10^{6} \mathrm{~kg}$ & & & & & \\
Production (rolling year averages) & 28.4 & 26.2 & 29.3 & 26.9 & 27.2 \\
Milk, kg of milk/cow per day & 4.34 & 4.49 & 4.22 & 4.37 & 4.61 \\
Fat, \% & 3.51 & 3.52 & 3.44 & 3.51 & 3.50 \\
Protein, $\%$ & & & & & 35 \\
Udder health, rolling year averages & 35 & 50 & 40 & 35 & 32 \\
Clinical cases, $\mathrm{n}$ & 120 & 163 & 209 & 292 & 263 \\
Bulk tank SCC, $10^{3}$ cells $/ \mathrm{mL}$ & 13 & 14.5 & 20.7 & 25.7 & 26.1 \\
Cows with SCC $>250,000, \%$ & & & &
\end{tabular}

to 100 DIM. For clinical mastitis, the survival analysis also was performed up to 30 DIM. Only first quarter cases were taken into account for the clinical mastitis analyses, and first cow cases for the subclinical mastitis analyses. Survival analyses were carried out in R. Significance was set at $P<0.05$

\section{RESULTS}

\section{General}

Descriptive results are summarized in Table 2. The mean length of the dry period was 8 wk $(54 \mathrm{~d}$, median $7 \mathrm{wk})$. Cows were sampled at the start of the dry period (T0), at a mean of $4 \mathrm{wk}(26 \mathrm{~d}$, median $4 \mathrm{wk})$ and 2 wk (11 d, median 2 wk) before parturition and within $24 \mathrm{~h}$ after calving. In total, 60 clinical quarter cases (5 repeated quarter cases included), 46 first clinical cow cases, and 73 first subclinical cow cases occurred in the first 3 mo of lactation. From the first clinical cow cases, 28 were in the high group. The number of first clinical quarter cases and first subclinical cow cases per farm and group is shown in Table 3. In total, 5 repeated quarter cases occurred. Of those 5 repeated quarter cases, 4 were in the high group and 4 occurred within $14 \mathrm{~d}$ after the first case. Only 1 repeated quarter case in the high group occurred, $29 \mathrm{~d}$ after the first case.

\section{Group and Group × Time Interaction}

Differences between treatment groups and time trends are summarized in Table 4 and Figure 2. At the start of the dry period, no differences between treatment groups were found for vitamin E concentration and the vitamin E:cholesterol ratio. After supplementation, vitamin $\mathrm{E}$ concentration and the vitamin
E:cholesterol ratio in blood were higher in the high group. No group differences were found for cholesterol, so the higher ratio in the high group indicated a higher vitamin $\mathrm{E}$ concentration per lipoprotein particle. In the low group, vitamin E concentrations decreased during the entire dry period, whereas in the high group, vitamin E concentrations started to decrease 2 wk before parturition. The vitamin E:cholesterol ratio increased in the high group in the first $3 \mathrm{wk}$ of supplementation and remained steady until calving. In the low group, the vitamin E:cholesterol ratio showed a decrease at calving compared with the first measurement.

The results of differences in vitamin $\mathrm{E}$ level between cows developing clinical mastitis and healthy cows are summarized in Table 5 and Figure 3. Vitamin E levels in cows that developed clinical mastitis in the low group seemed to be somewhat higher during the dry period. Although no significant group differences were found, the mean vitamin $\mathrm{E}$ level in the mastitis cows was numerically higher at dry off in both the high and low group.

The results of differences in vitamin E level at dry off between primi- and multiparous cows are summarized in Table 6. Vitamin E blood concentration differed $(P<0.001)$ at the start of the intervention between primi- and multiparous cows on the 3 farms where heifers were included. The mean vitamin $\mathrm{E}$ blood level of multiparous cows at dry off was $17.88 \mu \mathrm{mol} / \mathrm{L}$, whereas primiparous cows started the experiment with a mean level of $9.10 \mu \mathrm{mol} / \mathrm{L}$.

\section{Relative Risk}

The farm-corrected Mantel-Haenszel relative risk (MH RR) of developing clinical mastitis with 3,000 IU of vitamin E supplementation was 1.7 (95\% CI, 
Table 3. Number and percentage of first clinical quarter cases and first subclinical cow cases per farm and group in the first $100 \mathrm{DIM}^{1}$

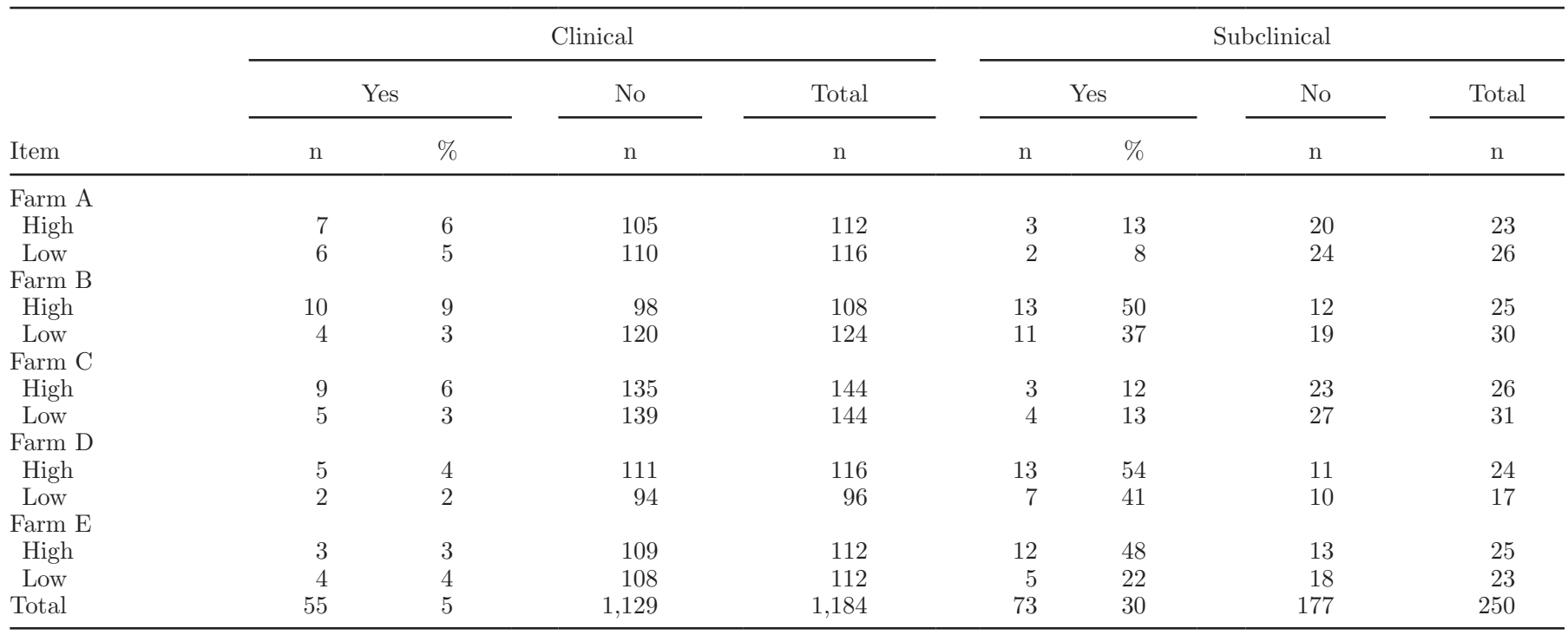

${ }^{1}$ Primi- and multiparous cows were both included.

1.0-2.8). The MH RR of developing subclinical mastitis with 3,000 IU vitamin E supplementation was 1.5 (95\% CI, 1.0-2.2). The crude relative risk of developing clinical mastitis with a starting vitamin E level above $14.5 \mu \mathrm{mol} / \mathrm{L}$ at dry off in the unsupplemented group was 3.1 (95\% CI. 0.9-10.3). Because in 4 of the farms no clinical cases occurred in the cows starting with a vitamin $\mathrm{E}$ level below $14.5 \mathrm{\mu mol} / \mathrm{L}$, only the crude relative risk is reported. The $\mathrm{MH} \mathrm{RR}$ of developing clinical mastitis with a starting vitamin E level $>14.5 \mu \mathrm{mol} / \mathrm{L}$ in the supplemented group was 1.3 (95\% CI. 0.6-2.9). Overall, the MH RR of developing clinical mastitis with a starting vitamin E level $>14.5 \mu \mathrm{mol} / \mathrm{L}$ was $1.9(95 \%$ CI, 1.0-3.7).

\section{Survival Analysis}

Figure 4 shows the survival curves of new clinical and subclinical cases in the high and low groups for the first

Table 4. Results of the Student's $t$-tests between the high- and low-supplemented group and the linear mixed models with treatment group, time, parity, and treatment group $\times$ time interaction as fixed effects, and cow, time, farm, and time and cow within farm as random effects for the dependent variables $\alpha$-tocopherol and the $\alpha$-tocopherol:cholesterol ratio in blood ${ }^{1}$

\begin{tabular}{|c|c|c|c|c|c|c|}
\hline Item & Group & $\mathrm{n}$ & Mean & SD & \multicolumn{2}{|c|}{$P$-value ${ }^{2}$} \\
\hline \multirow[t]{2}{*}{ Start dry period } & High & 145 & 15.93 & 5.84 & 0.933 & 0.516 \\
\hline & Low & 145 & 15.97 & 5.66 & & \\
\hline 4 wk before calving & High & 138 & 16.16 & 4.58 & 0.000 & 0.000 \\
\hline 2 wk before calving & Low & 139 & 10.25 & 3.20 & & \\
\hline \multirow[t]{2}{*}{ Calving } & High & 147 & 9.27 & 2.67 & 0.000 & 0.000 \\
\hline & Low & 146 & 6.80 & 1.85 & & \\
\hline \multicolumn{7}{|c|}{$\alpha$-Tocopherol:cholesterol ratio, $\mathrm{mmol} / \mathrm{L}$} \\
\hline \multirow[t]{2}{*}{ Start dry period } & High & 145 & 4.03 & 1.04 & 0.958 & 0.720 \\
\hline & Low & 145 & 4.01 & 0.86 & & \\
\hline 4 wk before calving & High & 137 & 5.58 & 1.02 & 0.000 & 0.000 \\
\hline
\end{tabular}

${ }^{1}$ Displayed are the numbers of cows for the high and low vitamin E groups per time period (n), mean, SD, $P$-values of difference between groups for the different periods, and the treatment group $\times$ time interaction effects. Both primi- and multiparous cows were included.

${ }^{2}$ Statistical tests were carried out on log-transformed vitamin $\mathrm{E}$ and log-transformed vitamin E:cholesterol ratio values. 
100 DIM. Clinical cases that occurred at the end of the dry period (between 2 and 0 wk before calving) were set at calving day. In the high group, more new clinical quarter cases from 100 and $30 \mathrm{DIM}(P=0.075$ and $P$ $=0.045$, respectively), and more new subclinical cows from 5 to 100 DIM $(P=0.044)$, occurred, compared with the low group. In all survival analyses, the 5 farms showed the same trend of more clinical and subclinical cases in the high group (results not shown).

\section{DISCUSSION}

Clinical and subclinical mastitis incidences were significantly higher in the group receiving a daily dry cow mineral mix with 3,000 IU of vitamin E/d compared with the $135 \mathrm{IU}$ of vitamin $\mathrm{E} / \mathrm{d}$ group on 5 dairy farms with historically high mastitis incidence. Although this is in contrast with previous studies that showed positive effects (Smith et al., 1984; Weiss et al., 1990a; Moyo et al., 2004) or no effects (LeBlanc et al., 2004; Persson Waller et al., 2007), the importance of these negative results should not be underestimated. The field study and even the majority of the analyses were carried out blinded, and for that reason, results are unbiased. Moreover, dry cows within each farm were randomly divided in 2 experimental groups, analyses at pen level within farm as experimental unit were almost significant for both clinical and subclinical mastitis (results not shown), and all 5 farms showed the same trend in the survival analysis of higher (sub)clinical mastitis incidences in the high group (results not shown). Further research is required to confirm these possible adverse effects. In such studies, it will be necessary to randomize on cow level and record exact levels of DMI including vitamin $\mathrm{E}$ to investigate the exact relationship between high vitamin E level and (udder) health.

The definition of a clinical mastitis case was farmerdiagnosed, but similar for animals in both groups within farms. As previously mentioned, farmers did not know which group was high and which was low. The definition of a subclinical mastitis case is more difficult because no consensus on this definition exists. In the present study, a subclinical case was defined as a first SCC elevation >100,000 cells/mL (Hillerton, 1999; Halasa et al., 2009) between 5 and 100 DIM not related to a clinical case; high-SCC cows were excluded from the analysis (see Figure 1). Changing the threshold in the definition to 200,000 cells/mL did not result in other trends of the survival analysis on the different farms (results not shown). The absolute number of new subclinical cases was higher for the threshold of 100,000 cells / mL compared with the threshold of 200,000 cells/ $\mathrm{mL}$.
In the present study, the vitamin E level in the dry cow mineral mix fed to the high group was higher than the NRC recommendations of $1.8 \mathrm{IU}$ of vitamin $\mathrm{E} / \mathrm{kg}$ of BW in the dry period. Although the level of 3,000 IU of vitamin $\mathrm{E} / \mathrm{d}$ is not recommended by the NRC (2001), it is not an unusual amount. Weiss et al. (1997) used $1,000 \mathrm{IU}$ in the first $46 \mathrm{~d}$ of the dry period and 4,000 IU

a)

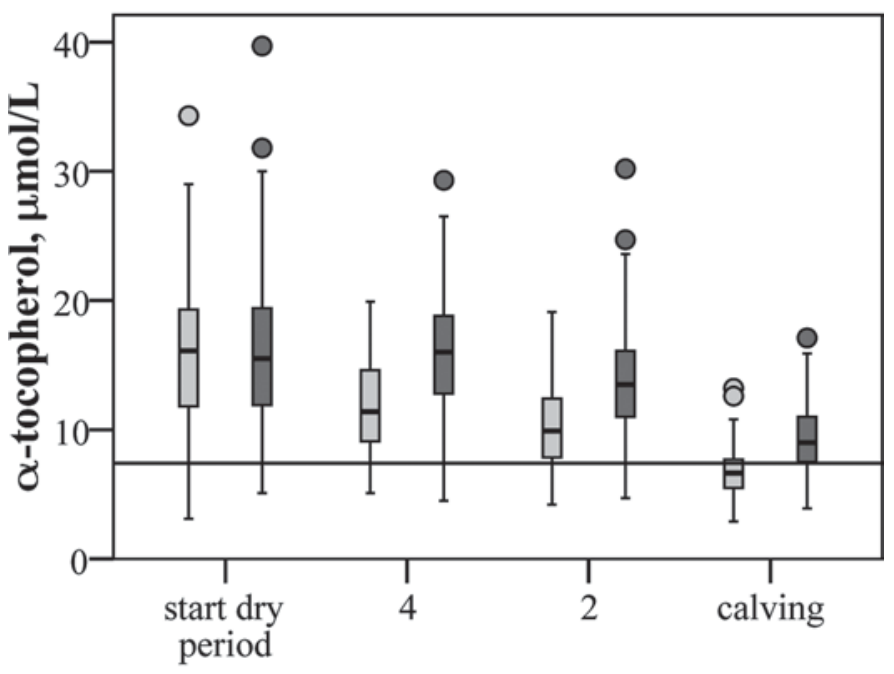

Weeks before calving

b)

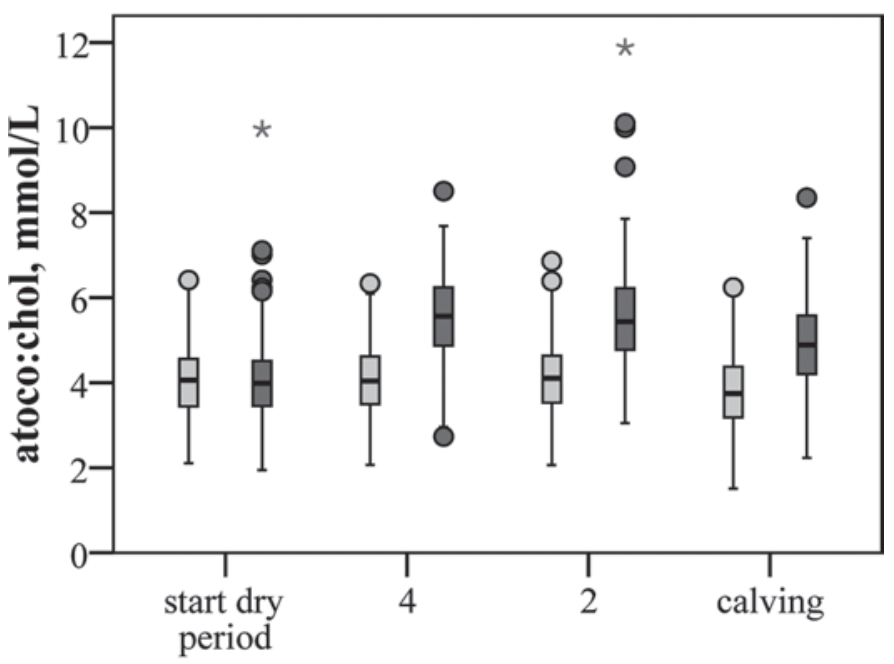

\section{Weeks before calving}

Figure 2. (a) Blood $\alpha$-tocopherol and (b) the $\alpha$-tocopherol:cholesterol (atoco:chol) ratio in the low (light-gray box plots) and high vitamin E groups (dark-gray box plots) during the dry period. Medians and quartiles are displayed in the box. Upper and lower bar represent 97.5 and 2.5 percentiles, respectively. Point markers indicate outliers and asterisks indicate extreme outliers. In (a), the Dutch minimum reference of $7.4 \mu \mathrm{mol} / \mathrm{L}$ is shown. 
Table 5. Results of Student's $t$-tests between healthy and mastitis cows ${ }^{1}$

\begin{tabular}{|c|c|c|c|c|c|}
\hline Group & Cows & $\mathrm{n}$ & $\begin{array}{c}\text { Mean, } \\
\mu \mathrm{mol} / \mathrm{L}\end{array}$ & $\mathrm{SD}$ & $P$-value ${ }^{2}$ \\
\hline \multicolumn{6}{|l|}{ High vitamin E group } \\
\hline \multirow[t]{2}{*}{ Start dry period } & Healthy & 117 & 15.68 & 5.82 & 0.296 \\
\hline & Mastitis & 28 & 16.95 & 5.92 & \\
\hline \multirow[t]{2}{*}{4 wk before calving } & Healthy & 111 & 16.43 & 4.38 & 0.082 \\
\hline & Mastitis & 27 & 15.10 & 5.28 & \\
\hline \multirow[t]{2}{*}{2 wk before calving } & Healthy & 114 & 13.89 & 3.96 & 0.338 \\
\hline & Mastitis & 27 & 13.32 & 4.52 & \\
\hline \multirow[t]{2}{*}{ Calving } & Healthy & 119 & 9.26 & 2.69 & 0.866 \\
\hline & Mastitis & 28 & 9.53 & 2.60 & \\
\hline \multicolumn{6}{|l|}{ Low vitamin E group } \\
\hline \multirow[t]{2}{*}{ Start dry period } & Healthy & 128 & 15.69 & 5.64 & 0.103 \\
\hline & Mastitis & 17 & 18.03 & 5.49 & \\
\hline \multirow{2}{*}{4 wk before calving } & Healthy & 125 & 11.71 & 3.55 & 0.433 \\
\hline & Mastitis & 16 & 12.55 & 3.90 & \\
\hline \multirow[t]{2}{*}{2 wk before calving } & Healthy & 121 & 10.20 & 3.29 & 0.433 \\
\hline & Mastitis & 18 & 10.64 & 2.59 & \\
\hline \multirow[t]{2}{*}{ Calving } & Healthy & 129 & 6.86 & 1.86 & 0.240 \\
\hline & Mastitis & 17 & 6.33 & 1.79 & \\
\hline
\end{tabular}

in the last $14 \mathrm{~d}$ and reported positive effects from these high amounts on udder health. Politis et al. (2004) used 3,000 IU antepartum and 1,000 postpartum and described improved bovine leukocyte function (Politis et al., 2004). Furthermore, it was recently reported that 3,000 IU of vitamin E supplemented from $8 \mathrm{wk}$ antepartum to 2 wk postpartum decreased oxidative damage to the liver (Bouwstra et al., 2008). The decision to supplement with 3,000 IU of vitamin $\mathrm{E} / \mathrm{d}$ was based on these earlier results.

In agreement with other studies (Weiss et al., 1990b; Herdt and Smith, 1996), extra daily supplementation of vitamin E resulted in higher vitamin E blood levels and a higher vitamin E:cholesterol ratio. Also in accordance with other studies (Goff and Stabel, 1990; Herdt and Smith, 1996), cows showed a decreasing vitamin E level around calving, starting from $4 \mathrm{wk}$ before calving in the low group and 2 wk before calving in the high group. In both groups, the lowest level was measured on the day of calving.

Although time trends and differences in vitamin $\mathrm{E}$ between groups are in agreement with results found by others, the mean vitamin $\mathrm{E}$ level at dry off for the cows used in this experiment was 2 to 3 times higher than starting levels for cows in other reports (Weiss et al., 1990b; LeBlanc et al., 2002). Moreover, vitamin E supplementation during the dry period in other studies led to comparable vitamin $\mathrm{E}$ levels in the supplemented group, whereas the control group in most other studies had much lower levels compared with the control group of this study. The high vitamin E blood level at dry off in this study probably caused the control group to remain relatively high over the dry period. The high vitamin E level at dry off seems the most reasonable explanation for the adverse results of the present study. Supplementation of vitamin $\mathrm{E}$ has a beneficial effect in cows with suboptimal blood levels (Smith et al., 1984; Weiss et al., 1990a). Although not expected, we found evidence for the existence of a maximum upper limit in addition to the already available lower reference value of $7.4 \mu \mathrm{mol} / \mathrm{L}$ (Weiss, 1998). The vitamin E status of dairy cows at the start of the dry period seemed to be important to finding beneficial, neutral, or detrimental effects. Even in the unsupplemented group of this study, absolute vitamin E level at dry off was an almost significant predictor for clinical mastitis. Baldi (2005) reported a maximum measured $\alpha$-tocopherol plasma concentration of $5.42 \mu \mathrm{g} / \mathrm{mL}$ following intraruminal administration of a gelatin capsule containing 5,000 IU of vitamin E, with a concentration of $5.42 \mu \mathrm{g} / \mathrm{mL}$ plus $1 \mu \mathrm{g} / \mathrm{mL}(6.42 \mu \mathrm{g} / \mathrm{mL})$ defined as "high at dry off" in this study. Converted to micromoles per liter, the "high at dry off" level is approximately $14.5 \mu \mathrm{mol} / \mathrm{L}$. The risk of developing clinical mastitis with a starting vitamin E blood concentration $>14.5 \mu \mathrm{mol} / \mathrm{L}$ was 3 times higher in the unsupplemented group and almost 1.5 times higher in the supplemented group compared with cows with vitamin $\mathrm{E}$ concentrations at dry off of less than $14.5 \mu \mathrm{mol} / \mathrm{L}$. These nonsignificant differences between the treatment groups might indicate the following. Both treatment groups started with the same vitamin $\mathrm{E}$ levels, and thus with the same "high at dry 
off" relative risk. Subsequently, in the supplemented group, the additional vitamin $\mathrm{E}$ during the full dry period caused additional risk of clinical mastitis, estimated at approximately 1.5 times higher, regardless of vitamin $\mathrm{E}$ level at dry off. This additional risk from supplementation could be due to a longer duration of high vitamin $\mathrm{E}$ levels in this population of animals, thereby reducing the relative importance of the "high at dry off" risk as a single risk factor. The high vitamin $\mathrm{E}$ levels may have been a risk factor for developing mastitis in previous lactation(s) as well, and might have contributed to the high (sub)clinical mastitis incidence on the selected farms. But as both treatment groups had the same starting level at dry off, the difference in mastitis incidence between groups can only be explained by the vitamin E supplementation at 3,000 $\mathrm{IU} / \mathrm{d}$. Therefore, it seems that both a high level at dry off and a high level during the dry period are risk factors for developing clinical mastitis. Because the study design was not optimized for a comparison of vitamin E level between cows with and without mastitis, the total number of mastitic cows may have been too low to reach significance in the Student's $t$-test analysis.

It remains unclear why cows in this experiment had such high vitamin $\mathrm{E}$ blood levels at the end of the lactation period; however, some hypotheses can be proposed. One explanation might be that the experiment was conducted on farms with a high incidence of mastitis. The existing mastitis problems might have led to changes in feed management in the years before the field study started. In addition, feed manufacturers may have changed vitamin E levels of concentrates for lactating cows based on results of prior studies and NRC (2001) recommendations. Prior to the field trial, a pilot study was carried out in summer 2005 on 98 animals from 26 farms. The main goal of the pilot study was to evaluate the vitamin E levels in Dutch dairy cows 1 wk before expected calving date. Results showed blood concentrations below the reference value of 7.4 $\mu \mathrm{mol} / \mathrm{L}$ to be very common, even in supplemented cows. Supplementation in the dry period was at a cow level of $1,000 \mathrm{IU} / \mathrm{d}$, but $30 \%$ of the animals still had blood concentrations $<7.4 \mu \mathrm{mol} / \mathrm{L}(\mathrm{n}=52)$, and $60 \%$ of the nonsupplemented cows $(\mathrm{n}=46)$ had concentrations $<7.4 \mu \mathrm{mol} / \mathrm{L}$ (Bouwstra et al., 2009). Between 2005 and 2008, vitamin E and mastitis became a more important topic in herds with mastitis problems. All 5 farms already used levels of vitamin E supplementation above the NRC (2001) recommendation as part of their normal dry cow management. Indeed, enrollment for this field study was difficult because farmers were asked to remove vitamin $\mathrm{E}$ (to form the low group), rather than add vitamin $\mathrm{E}$ (to form the high group).
On the 3 farms where heifers were included in the experiment, a striking difference in initial vitamin $\mathrm{E}$ status was found between primi- and multiparous cows (9.10 vs. $17.88 \mu \mathrm{mol} / \mathrm{L}$ at T0 respectively). This differ-

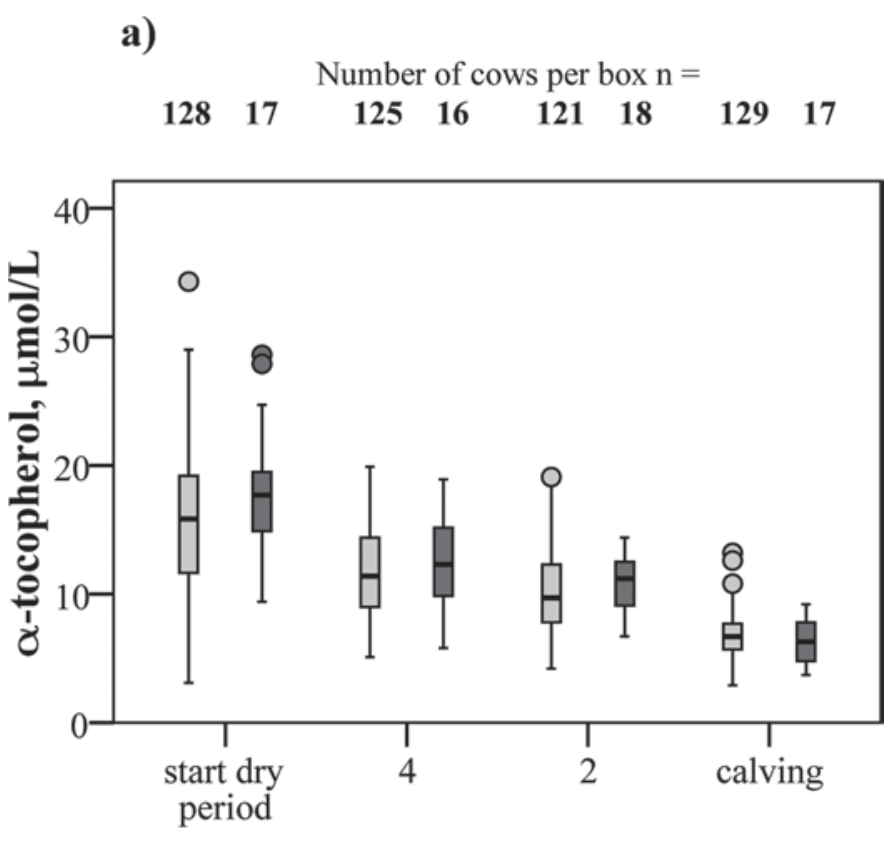

Weeks before calving

b)
$117 \quad 28$

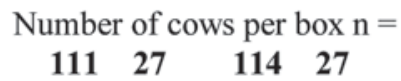
$119 \quad 28$

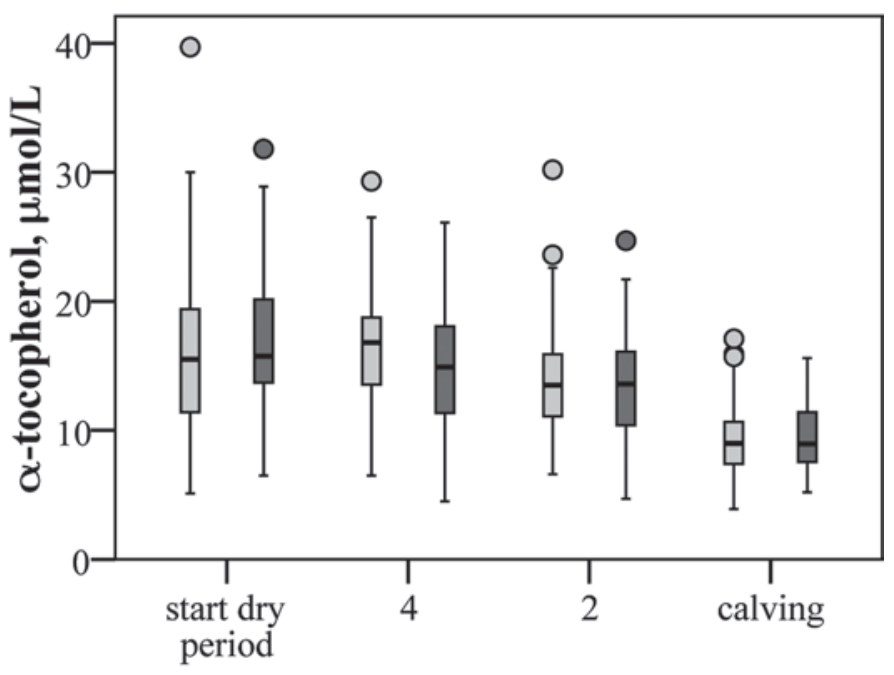

Weeks before calving

Figure 3. Blood vitamin $\mathrm{E}$ in the healthy cows (light-gray box plots) and clinical mastitis cows (dark-gray box plots) during the dry period for the (a) low and (b) high vitamin E groups. Medians and quartiles are displayed in the box. Upper and lower bar represent 97.5 and 2.5 percentiles, respectively. Point markers indicate outliers. 
Table 6. Results of the Student's $t$-tests between primi- and multiparous cows ${ }^{1}$

\begin{tabular}{|c|c|c|c|c|c|c|}
\hline Item & $\mathrm{n}$ & $\begin{array}{c}\text { Mean, } \\
\mu \mathrm{mol} / \mathrm{L}\end{array}$ & $\begin{array}{c}\text { Min, } \\
\mu \mathrm{mol} / \mathrm{L}\end{array}$ & $\begin{array}{c}\mathrm{Max} \\
\mu \mathrm{mol} / \mathrm{L}\end{array}$ & $\mathrm{SD}$ & $P$-value ${ }^{2}$ \\
\hline \multicolumn{7}{|l|}{ Farm A } \\
\hline Primiparous & 0 & - & - & - & - & - \\
\hline Multiparous & 57 & 20.48 & 11.80 & 39.70 & 5.44 & - \\
\hline \multicolumn{7}{|l|}{ Farm B } \\
\hline Primiparous & 21 & 10.20 & 5.90 & 14.00 & 2.02 & 0.000 \\
\hline Multiparous & 34 & 19.78 & 11.50 & 31.80 & 5.67 & 0.000 \\
\hline \multicolumn{7}{|l|}{ Farm C } \\
\hline Primiparous & 0 & - & - & - & - & - \\
\hline Multiparous & 71 & 17.71 & 11.30 & 28.20 & 3.30 & - \\
\hline \multicolumn{7}{|l|}{ Farm D } \\
\hline Primiparous & 23 & 7.91 & 5.50 & 11.20 & 1.85 & 0.000 \\
\hline Multiparous & 29 & 15.07 & 7.90 & 20.90 & 3.22 & 0.000 \\
\hline \multicolumn{7}{|l|}{ Farm E } \\
\hline Primiparous & 20 & 9.33 & 3.10 & 16.60 & 3.24 & 0.000 \\
\hline Multiparous & 35 & 14.49 & 7.60 & 20.30 & 3.20 & 0.000 \\
\hline
\end{tabular}

ence $(P<0.001)$ might confirm our hypothesized increase in the use of vitamin $\mathrm{E}$ in lactation concentrates. Because mastitis problems mainly occur in multiparous cows, changes in feed strategies on the farm level are expected to be applied in the lactating group and not in the young stock. This result might be an indication of increased concentrations of vitamin E not only in dry cow supplements, but also in lactating minerals and concentrates over the last few years.

It was reported that most clinical mastitis cases in the first month of lactation find their origins in the dry period, whereas cases that occur after 30 DIM often develop during lactation (Green et al., 2002). In the present study, vitamin $\mathrm{E}$ was supplemented during the dry period. For that reason, it can be argued that the outcome should be clinical cases in the first month of lactation. However, the main difference between this study and other studies on vitamin $\mathrm{E}$ is the adverse outcome. Because the working mechanism of vitamin $\mathrm{E}$ in case of a harmful effect is currently unknown, we analyzed both 30- and 100-DIM periods. Both analyses gave the same results; namely, a higher clinical mastitis incidence in the high group, and the same trends on each of the 5 farms from both survival analyses (results not shown).

Although this is the first report of an adverse effect of vitamin $\mathrm{E}$ in dairy cows, negative effects of high levels of vitamin $\mathrm{E}$ supplements in humans were recently published. Brigelius-Flohé (2007) reported that the outcome of large-scale clinical trials conducted to prove a benefit of vitamin $\mathrm{E}$ in the recurrence or progression of coronary heart diseases and cancer in human was disappointing. Vitamin E did not provide benefits to patients with cardiovascular diseases, cancer, diabetes, or hypertension. Harmful events and worsening of preexisting diseases have been reported. The author hypothesized that high doses of vitamin E may lead to an induction of the drug-metabolizing system in the liver. Other researchers reported a meta-analysis that showed daily supplementation with $\geq 400$ IU of vitamin $\mathrm{E}$ to be associated with increased mortality (Miller et al., 2005). The authors concluded that a complete understanding of vitamin $\mathrm{E}$ actions at the cell level does not yet exist and its clinical effects are still in dispute. Recently, Winterbone et al. (2007) described that vitamin $\mathrm{E}$ in high amounts may cause oxidative damage on the DNA level in diabetes patients, again, an indication of adverse effects of high vitamin E levels.

Our current working hypotheses of the mechanism by which high vitamin $\mathrm{E}$ increases risk of mastitis in dairy cattle follow from the above-mentioned reports. The first hypothesis is the vitamin $\mathrm{E}$ as radical theory. Vitamin $\mathrm{E}$ is described as a powerful antioxidant that lowers oxidative stress and thereby influences the health of dairy cows in a positive way (Burton and Traber, 1990; Miller et al., 1993). Oxidative stress occurs when the balance between antioxidants and free oxygen radicals is disturbed and leads to damage of biological macromolecules and disruption of cell structures (Blokhina et al., 2003). In the present study, the high levels of vitamin $\mathrm{E}$ at dry off combined with high supplementation could have overloaded the oxidative stress cascade with vitamin $\mathrm{E}$, whereas the other molecules in the cascade were not able to neutralize all vitamin $\mathrm{E}$ radicals. In this case, vitamin $\mathrm{E}$ in the presence of oxidative stress might function as a prooxidant rather than as an 
a)

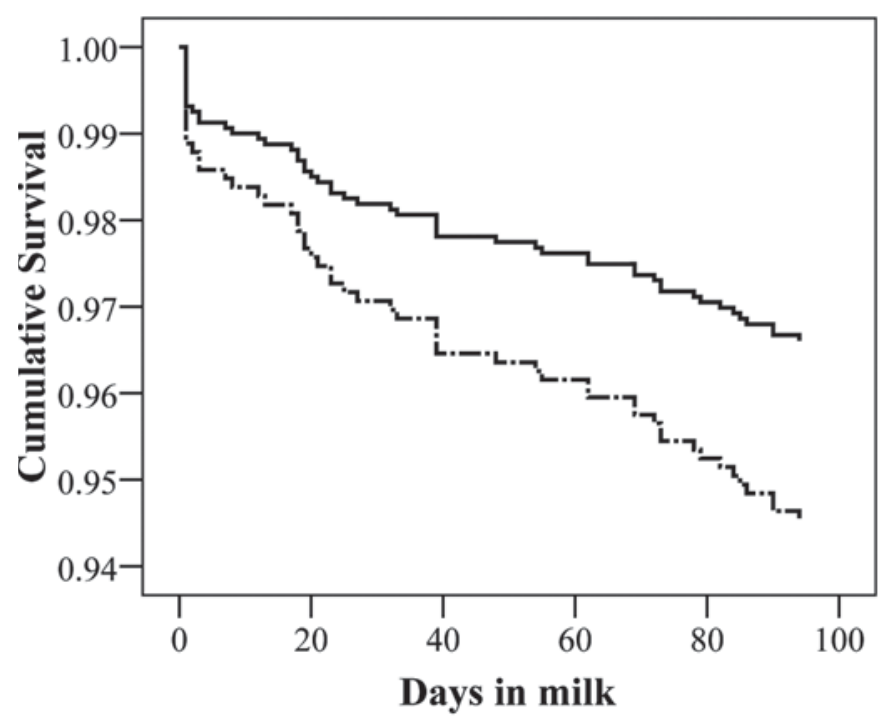

b)



Figure 4. Survival curves of time to first (a) clinical quarter cases from calving to 100 DIM and (b) to first subclinical cow cases from 5 to 100 DIM in the high $(-\cdot-)$ and low $(-)$ vitamin E groups. $P$-values were 0.075 for clinical and 0.044 for subclinical survival analysis.

antioxidant. The excessive vitamin E supplementation, where other antioxidants of the oxidative stress cascade are reduced, might allow for the increase in oxidative stress. Radicals cause cell damage and might influence the functions of immune cells (Politis et al., 2004), resulting in increased mastitis risk. To better understand the process, we have used the "vitamin E regeneration system" (VERS) hypothesis. For more details about this hypothesis, see Bouwstra et al. (2010).
Another hypothesis comprises the liver theory. Especially in periparturient cows, the liver performs essential functions in metabolism of glucose, lipids, triacylglycerol, and cholesterol (Grummer, 2008). Various authors have reported a relationship between metabolic changes and liver function (Loor et al., 2005). The mentioned induction of the drug-metabolizing system in the liver in case of vitamin $\mathrm{E}$ toxicity could influence the health of transition dairy cows in a negative way. We were unable to study this hypothesis further with our current data.

In general, further research is necessary to describe the pathway of the detrimental effect of vitamin $\mathrm{E}$ and to determine at what level of supplementation vitamin $\mathrm{E}$ is contraindicated.

\section{CONCLUSIONS}

It is important to consider a possible negative effect of vitamin E supplementation. Currently, vitamin E is commonly supplemented based on the argument that it improves udder health and lowers the incidence of other diseases in periparturient cows. However, advising extra vitamin $\mathrm{E}$ supplementation without knowing the current vitamin E status on a farm might be hazardous. Because of the popularity of vitamin E supplementation, further research into potential adverse effects is warranted. It is recommended to investigate at what threshold vitamin $\mathrm{E}$ shows adverse effects before new clinical trials with high doses of vitamin $\mathrm{E}$ are started.

\section{ACKNOWLEDGMENTS}

The authors thank the participating farmers and are grateful to Provimi BV (Rotterdam, the Netherlands) for donating the vitamin E. The authors acknowledge Y. H. Schukken (Ithaca, NY) and T. J. G. M. Lam (Deventer, the Netherlands) for critical comments, E. Pels Rijcken and the students for carrying out the field trial, and H. Cremers and P. Beekhof for excellent technical assistance. This study is part of the 5 -yr mastitis program of the Dutch Udder Health Centre and was financially supported by the Dutch Dairy Board.

\section{REFERENCES}

Baldi, A. 2005. Vitamin E in dairy cows. Livest. Prod. Sci. 98:117122.

Baldi, A., G. Savoini, L. Pinotti, E. Monfardini, F. Cheli, and V. Dell'Orto. 2000. Effects of vitamin E and different energy sources on vitamin $\mathrm{E}$ status, milk quality and reproduction in transition cows. J. Vet. Med. A Physiol. Pathol. Clin. Med. 47:599-608.

Blokhina, O., E. Virolainen, and K. V. Fagerstedt. 2003. Antioxidants, oxidative damage and oxygen deprivation stress: A review. Ann. Bot. 91:179-194. 
Bouwstra, R. J., R. M. A. Goselink, P. Dobbelaar, M. Nielen, J. R. Newbold, and T. van Werven. 2008. The relationship between oxidative damage and vitamin $\mathrm{E}$ concentration in blood, milk, and liver tissue from vitamin E supplemented and nonsupplemented periparturient heifers. J. Dairy Sci. 91:977-987.

Bouwstra, R. J., M. Nielen, J. R. Newbold, E. H. J. M. Jansen, H. F. Jelinek, and T. van Werven. 2010. Vitamin E supplementation during the dry period in dairy cattle. Part II: Oxidative stress following vitamin E supplementation may increase clinical mastitis incidence postpartum. J. Dairy Sci. 93:5696-5706.

Bouwstra, R. J., M. Nielen, and T. van Werven.. 2009. Comparison of the oxidative status of vitamin E supplemented and nonsupplemented cows under field conditions. Tijdschr. Diergeneesk. 134:656-661.

Brigelius-Flohé, R. 2007. Adverse effects of vitamin E by induction of drug metabolism. Genes Nutr. 2:249-256.

Burton, G. W., and M. G. Traber. 1990. Vitamin E: Antioxidant activity, biokinetics, and bioavailability. Annu. Rev. Nutr. 10:357382.

Goff, J. P., and J. R. Stabel. 1990. Decreased plasma retinol, alpha-tocopherol, and zinc concentration during the periparturient period: Effect of milk fever. J. Dairy Sci. 73:3195-3199.

Green, M. J., L. E. Green, G. F. Medley, Y. H. Schukken, and A. J. Bradley. 2002. Influence of dry period bacterial intramammary infection on clinical mastitis in dairy cows. J. Dairy Sci. 85:25892599.

Grummer, R. R. 2008. Nutritional and management strategies for the prevention of fatty liver in dairy cattle. Vet. J. 176:10-20.

Halasa, T., M. Nielen, A. P. W. De Roos, R. Van Hoorne, G. de Jong, T. J. G. M. Lam, T. van Werven, and H. Hogeveen. 2009. Production loss due to new subclinical mastitis in Dutch dairy cows estimated with a test-day model. J. Dairy Sci. 92:599-606.

Herdt, T. H., and J. C. Smith. 1996. Blood-lipid and lactation-stage factors affecting serum vitamin $\mathrm{E}$ concentrations and vitamin $\mathrm{E}$ cholesterol ratios in dairy cattle. J. Vet. Diagn. Invest. 8:228232.

Hillerton, J. E. 1999. Redefining mastitis based on somatic cell count. IDF Bull. 345:4-6.

LeBlanc, S. J., T. F Duffield, K. E. Leslie, K. G. Bateman, J. TenHag, J. S. Walton, and W. H Johnson.. 2002. The effect of prepartum injection of vitamin $\mathrm{E}$ on health in transition dairy cows. J. Dairy Sci. 85:1416-1426.

LeBlanc, S. J., T. H. Herdt, W. M. Seymour, T. F. Duffield, and K. E. Leslie. 2004. Peripartum serum vitamin E, retinol, and betacarotene in dairy cattle and their associations with disease. J. Dairy Sci. 87:609-619.

Loor, J. J., H. M. Dann, R. E. Everts, R. Oliveira, C. A. Green, N. A. J. Guretzky, S. L. Rodriguez-Zas, H. A. Lewin, and J. K. Drackley.
2005. Temporal gene expression profiling of liver from periparturient dairy cows reveals complex adaptive mechanisms in hepatic function. Physiol. Genomics. 23:217-226.

Miller, J. K., E. Brzezinska-Slebodzinska, and F. C. Madsen. 1993. Oxidative stress, antioxidants, and animal function. J. Dairy Sci. 76:2812-2823.

Miller, E. R. III, R. Pastor-Barriuso, D. Dalal, R. A. Riemersma, L. J. Appel, and E. Guallar. 2005. Meta-analysis: High-dosage vitamin E supplementation may increase all-cause mortality. Ann. Intern. Med. 142:37-46.

Moyo, N., M. Nielen, C. Kruitwagen, and A. C. Beynen. 2004. Vitamin E and udder health: A meta-analysis. IDF, Maastricht, The Netherlands.

NRC. 2001. Nutrient Requirements of Dairy Cattle. National Academy Press, Washington, DC.

Politis, I., I. Bizelis, A. Tsiaras, and A. Baldi. 2004. Effect of vitamin E supplementation on neutrophil function, milk composition and plasmin activity in dairy cows in a commercial herd. J. Dairy Res. 71:273-278.

Smith, K. L., J. H. Harrison, D. D. Hancock, D. A. Todhunter, and H. R. Conrad. 1984. Effect of vitamin E and selenium supplementation on incidence of clinical mastitis and duration of clinical symptoms. J. Dairy Sci. 67:1293-1300.

Thrusfield, M., C. Ortega, I. de Blas, J. P. Noordhuizen, and K. Frankena. 2001. Win episcope 2.0: Improved epidemiological software for veterinary medicine. Vet. Rec. 148:567-572.

Persson Waller, K., C. H. Sandgren, U. Emanuelson, and S. K. Jensen. 2007. Supplementation of RRR- $\alpha$-tocopheryl acetate to periparturient dairy cows in commercial herds with high mastitis incidence. J. Dairy Sci. 90:3640-3646.

Weiss, W. P. 1998. Requirements of fat-soluble vitamins for dairy cows: A review. J. Dairy Sci. 81:2493-2501.

Weiss, W. P., J. S. Hogan, K. L. Smith, and K. H. Hoblet. 1990a. Relationships among selenium, vitamin $\mathrm{E}$, and mammary gland health in commercial dairy herds. J. Dairy Sci. 73:381-390.

Weiss, W. P., J. S. Hogan, D. A. Todhunter, and K. L. Smith. 1997. Effect of vitamin E supplementation in diets with a low concentration of selenium on mammary gland health of dairy cows. J. Dairy Sci. 80:1728-1737.

Weiss, W. P., D. A. Todhunter, J. S. Hogan, and K. L. Smith. 1990b. Effect of duration of supplementation of selenium and vitamin $\mathrm{E}$ on periparturient dairy cows. J. Dairy Sci. 73:3187-3194.

Winterbone, M. S., M. Sampson, S. Saha, J. Hughes, and D. Hughes. 2007. Pro-oxidant effect of alpha-tocopherol in patients with Type 2 Diabetes after an oral glucose tolerance test-A randomised controlled trial. Cardiovasc. Diabetol. 6:8. 